\title{
In-vitro Analysis of Ganoderma lucidum Extract Induces Cell Cycle Arrest and Apoptosis in MCF-12 Human Breast Cancer Cell
}

\author{
Reetu Gour $^{1 *}$ and A.P. Garg ${ }^{2}$
}

${ }^{1}$ Department of Microbiology, Ch. Charan Singh University, Meerut-250004 (India)

${ }^{2}$ School of Biological Engineering \& Life Sciences, Shobhit Institute of Engineering \&

Technology, (Deemed-to-be-University), Modipuram, Meerut-250110, India

*Corresponding author

\section{A B S T R A C T}

\begin{tabular}{|c|}
\hline Keywords \\
\hline $\begin{array}{l}\text { Ganoderma } \\
\text { lucidum, Breast } \\
\text { cancer, Cell cycle, } \\
\text { Apoptosis }\end{array}$ \\
\hline Article Info \\
\hline $\begin{array}{l}\text { Accepted: } \\
26 \text { August } 2020 \\
\text { Available Online: } \\
\text { 10 September } 2020\end{array}$ \\
\hline
\end{tabular}

\section{Introduction}

An increasing number of natural chemical compounds have been identified to be potent in the treatment of various major human diseases including cancer (1- 4). Many of these substances are found in oriental herbaceous plants. Recently, some chemopreventive extracts of herbaceous plants have been shown to be anti-tumorigenic $(5-8)$. Carcinogenesis is a multistage or multimechanism process, involving the irreversible alteration of a stem cell followed by the clonal proliferation of the initiated stem cell from which the acqui sition of the invasive and metastatic phenotypes are generated (the "progression" phase) (9). Cancer prevention or therapy may be accomplished at different steps of this process by different mechanisms. Mixed extract of herbaceous plants might contain different chemopreventive chemotherapeutic compounds with more than one mechanism of action, thus possessing a combination of different chemopreventive or chemotherapeutic effects. It is therefore very important to identify combination effects of mixed extract of herbaceous plants. 
Ganoderma lucidum, an oriental fungus, has been widely used as a medical drug product in China and other Asian countries. The fruiting bodies and cultured mycelia of Ganoderma lucidum have been demonstrated to possess anti-tumor activities, (10-18), neuroactive effects immunomodulatory activities (19 20). Although numerous studies on the effects of water ex- tracts of GL have been reported, $(10-15)$ in short is known regarding its alcohol extracts. It has been reported that the alcohol extract of Ganoderma lucidum can induce cell cycle arrest at transition from G1 to $\mathrm{S}$ phase in HeLa-cells17 this work was design to further investigate the anti-tumor effect of alcohol extract of Ganoderma lucidum and elucidate the potential mechanisms using an in vitro system. We found that the alcohol extract of Ganoderma lucidum was able to induce cell cycle arrest at G1 phase and induce apoptosis in MCF-12 cells in a time-dependent manner. The mechanisms might be mediated through upregulation of the expression of p21/Waf1-a cell cycle inhibitor, down-regulation cyclin D1, and up regulation of a pro-apoptotic BAX protein pathway.

\section{Materials and Methods}

\section{Cell culture}

MCF -12 cells (Manassas, ATCC, VA) were cultured in D-media4 supplemented with $10.5 \%$ FBS (Carlsbad, CA, Invitrogen).

Preparation of ethanol-soluble and acidic components from Ganoderma lucidum

Fruiting bodies of Ganoderma lucidum (1 kg) were extracted with ethanol $(90 \%, 101)$ for 24 $\mathrm{hr}$ at room temperature to give $30 \mathrm{~g}$ of solid extract. The ethanol extract was suspended in chloroform and extracted with a saturated $\mathrm{NaHCO}_{3}$ solution $3 \times$. The $\mathrm{NaHCO}_{3}$ phase was then collected and adjusted to $\mathrm{pH} 3$ with cold $\mathrm{HCl}$ solution $(7 \mathrm{~N})$. The resulting precipitates were extracted by chloroform, and $10.5 \mathrm{~g}$ ethanol-soluble and acidic components (ESAC) were obtained in the form of yellow solid.

\section{Cell proliferation assay}

The effects on cell proliferation were measured by MTT assay, which is based on the ability of live cells to convert tetrazolium salt into purple formazan. In short, the cells were seeded in 96-well micro- plates and incubated overnight. Then the cells were treated with different concentrations of the test compound $(100,250,350,450$ and 550 $\mu \mathrm{g} / \mathrm{ml})$ or its vehicle, ethanol $(0.8 \%)$ for 12 , 24,36 or $48 \mathrm{hr}$. At the end of these times, 20 $\mu \mathrm{l}$ of MTT stock solution $(5 \mathrm{mg} / \mathrm{ml}$, Sigma, St. Louis, MO) were added to each well and the plates were further incubated for $6 \mathrm{hr}$ at $36^{\circ} \mathrm{C}$. The supernatant was removed and 100 $\mu 1$ of DMSO were added to each well to solubilize the water-insoluble purple formazan crystals. The absorbency at a wavelength of $570 \mathrm{~nm}$ was measured with Multiscan MCC 340 microplate reader (Titertek, Huntsville, AL). All the measurements were performed in triplicate.

\section{Cell cycle analysis}

MCF-12 cells in exponential phase of growth were treated with the alcohol extract of Ganoderma lucidum $(550 \mu \mathrm{g} / \mathrm{ml})$ for the indicated times, then harvested by trypsinization, and washed $2 \times$ with ice-cold PBS and fixed by $75 \%$ ethanol at $-25^{\circ} \mathrm{C}$ for at least $30 \mathrm{~min}$. The fixed cells were then washed 2 times with ice-cold PBS and stained with $50 \mu \mathrm{g} / \mathrm{ml}$ of propidium iodide in the presence of $100 \mu \mathrm{g} / \mathrm{ml}$ of RNase for $30 \mathrm{~min}$. Cell cycle distribution was analyzed using FACS Calibur. Data from 10,000 cells per sample were collected and analyzed using the Cell Fit Cell analysis program. 


\section{Apoptosis assay}

The apoptotic effect of the alcohol extract of Ganoderma lucidum on MCF-12 cells were analyzed by nuclear DNA staining and DNA fragmentation assay. For nuclear DNA staining, control and compound-treated cells were fixed in $4 \%$ para-formaldehyde in PBS for $20 \mathrm{~min}$, washed with PBS, stained with Hoechst 33258 at $1 \mu \mathrm{g} / \mathrm{ml}$ in PBS for $20 \mathrm{~min}$. Stained cells were washed $2 \times$ with PBS. The changes in nuclei were observed with a fluorescent microscope (Olympus, Melville, NY) through UV-filter. For DNA fragmentation assay, either detached and attached control or com- pound-treated cells were harvested by scraping and centrifugation. The cells were then lysed with lysis buffer $(5 \mathrm{mM}$ Tris [pH 8.0] $20 \mathrm{mM}$ EDTA, $0.5 \%$ Triton X-100) on ice for $45 \mathrm{~min}$. Fragmented DNA in the supernatant fraction after centrifugation at $14,000 \mathrm{rpm}$ (45 min at $4^{\circ} \mathrm{C}$ ) was extracted $2 \times$ with phenolchloroform-isoamyl alcohol (25:24:1, v/v) and once with chloroform and then precipitated with ethanol and $3 \mathrm{M}$ sodium acetate overnight at $-20^{\circ} \mathrm{C}$. The DNA pellet was washed once with $70 \%$ ethanol and resuspended in Tris-EDTA buffer $(\mathrm{pH}$ 8.0) with $100 \mu \mathrm{g} / \mathrm{ml}$ RNase and incubated at $37^{\circ} \mathrm{C}$ for 2 hr. The DNA fragments were separated by $1.8 \%$ agarose gel electrophoresis and visualized under UV light.

\section{Western blot analysis}

MCF-12 cells were grown in a $10 \mathrm{~cm}$ dish. When density reached $85-90 \%$ then the confluence cells were treated with alcohal extact of Ganoderma lucidum $(500 \mu \mathrm{g} / \mathrm{ml})$ for the indicated times. The cells was then washed once with ice-cold PBS and lysed with lysis buffer (25\% SDS containing $2 \mathrm{mM}$ phenylmethylsulfonyl fluoride, $10 \mathrm{mM}$ iodoacetamide, $\quad 0.1 \quad \mathrm{mM}$ sodium orthovanadate, $1.5 \mathrm{mM}$ leupeptin, $1 \mathrm{mM}$ antipain and $5 \mathrm{mM}$ sodium fluoride) for 10 $-20 \mathrm{~min}$. The lysates were sonicated $3 \times$ at 10 sec intervals, aliquoted and stored at $-25^{\circ} \mathrm{C}$. The protein concentration was determined by the Bio-Rad DC protein assay (Bio-Rad Laborato- ries, Hercules, CA). Equal amounts of protein $(20 \mu \mathrm{g} /$ lane $)$ were subjected to $12 \%$ SDS-PAGE and transferred to nitrocellulose membranes. The membranes were subsequently incubated with the corresponding initial (Primary) antibodies, as indicated, a rabbit anti- p21Cip1/WAF1 polyclonal antibody, a mouse anti-Bcl-2 mono- clonal antibody (Zymed Laboratories Inc., South San Francisco, CA); a mouse antip53 monoclonal antibody, a rabbit anti-Bax antibody (Sigma); a mouse anti-cyclin D1 antibody, a rabbit anti- cdk4 polyclonal antibody, a mouse anti-E2F-1 monoclonal anti- body, a mouse anti-PARP monoclonal antibody (Santa Cruz Bio- technology, Santa Cruz, CA); a rabbit anti-caspase-7 polyclonal antibody (Chemicon International Inc., Temecula, CA). Antibody detector was detected with the respective secondary antibody, ether or anti-rabbit IgG or antimouse IgG antibodies linked to horseradish peroxidase (Zymed). Antibody-bound proteins were detected by the ECL western blotting analysis system (Amersham Pharmacia Biotech, UK).

\section{Results and Discussion}

\section{Alcohol extract of Ganoderma lucidum inhibited proliferation of MCF-12 cells}

To evaluate the effects of alcohol extract of Ganoderma lucidum on the growth of MCF12 cells, the cells were treated with a series of concentrations of alcohol extract of Ganoderma lucidum from $100-550 \mu \mathrm{g} / \mathrm{ml}$ for $0,12,24,36$ and $48 \mathrm{hr}$. Cell growth was determined by MTT assay. As shown in Figure 1, alcohol extract of Ganoderma lucidum inhibited the proliferation of MCF-12 
cells in a time and dose dependent manner. After $48 \mathrm{hr}$ of treatment, at $500 \mu \mathrm{g} / \mathrm{ml}$, this alcohol extract caused nearly a $70 \%$ inhibition of cell growth compared to the control. This concentration was used in all further experiments.

\section{Alcohol extract of Ganoderma lucidum induced cell cycle arrest at G1 phase in MCF-12 cells}

To investigate the basis of the antiproliferative properties of alcohol extract of Ganoderma lucidum, cell cycle analyses were performed with flow cytometry. As shown in Figure 2, cells accumulated in the G1 phase, and the number of the cells in G1 phase increased gradually from 24- $48 \mathrm{hr}$ after treatment with the test compound. The number of cells in $\mathrm{S}$ and $\mathrm{G} 2 / \mathrm{M}$ phase decreased in same manner.

Alcohol extract of Ganoderma lucidum induced apoptosis in MCF-12 cells

To determine if exposure to alcohol extract of Ganoderma lucidum causes cell death by apoptosis in human breast cancer cells, Hoechst 33258 staining and DNA laddering were performed. The test compound was capable of inducing apoptosis in MCF-12 cells in a time-dependent manner, which was characterized by nuclear shrinkage, chromatin condensation and significant DNA fragmentation. The most significant effect was observed $36 \mathrm{hr}$ after the treatment.

Effects of alcohol extract of Ganoderma lucidum on the levels of P53, P21, cyclin D1, CDK4 and E2F in MCF-12 cells

To elucidate the mechanisms of alcohol extract of Ganoderma lucidum induced cell cycle arrest in MCF-12 cells, Western blot was performed to evaluate p21/Waf1-a cell cycle inhibitor, cyclin D1, cyclin-dependent protein kinase $4(\mathrm{cdk} 4)$ and transcription factor E2F. The p21 level was increased $12 \mathrm{hr}$ after treatment and remained elevated up to $48 \mathrm{hr}$ (Fig. 2). In contrast, the levels of cyclin D1, cdk4 and E2F decreased in a timedependent manner. No change was observed in protein expression of p53.

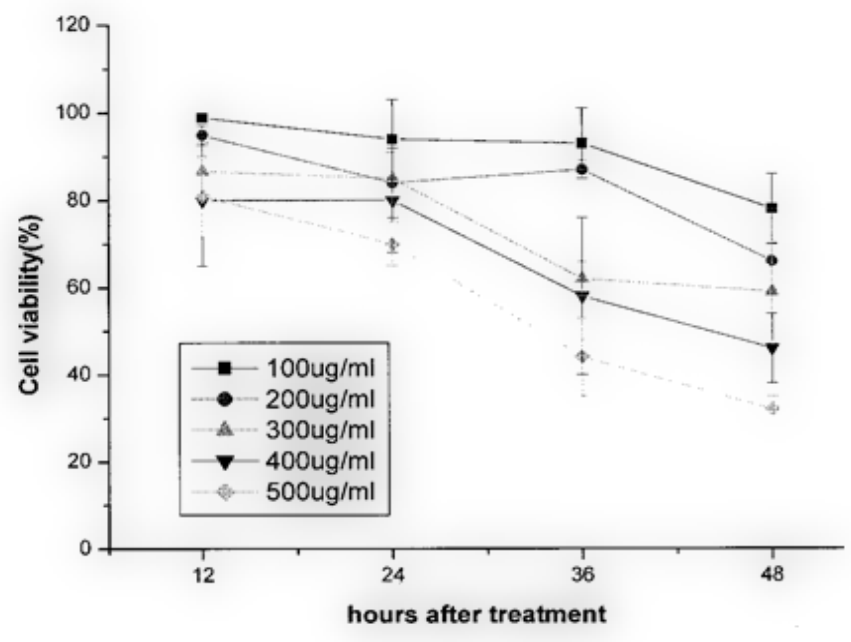

Figure.1 Inhibition of proliferation by Ganoderma lucidum. Cells were treated with various concentrations of test compound for indicated times, and cell viability was determined by the MTT assay 


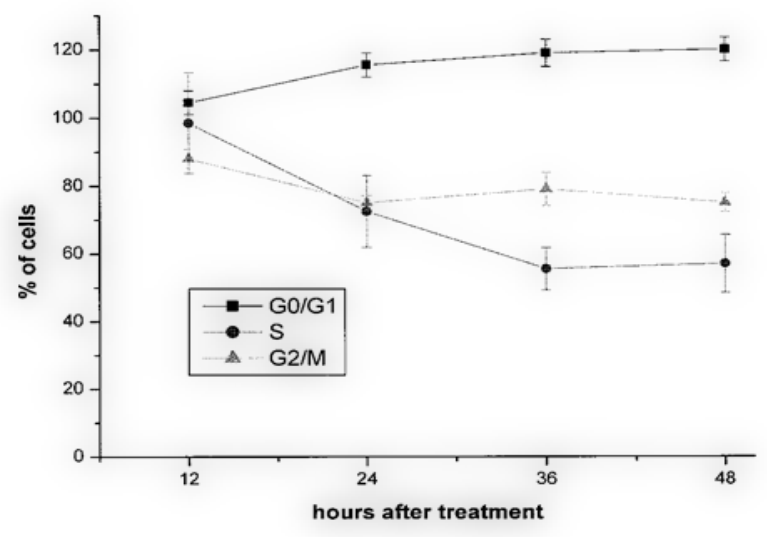

Figure.2 Cell cycle distribution in MCF-12 cells treated with Ganoderma lucidum

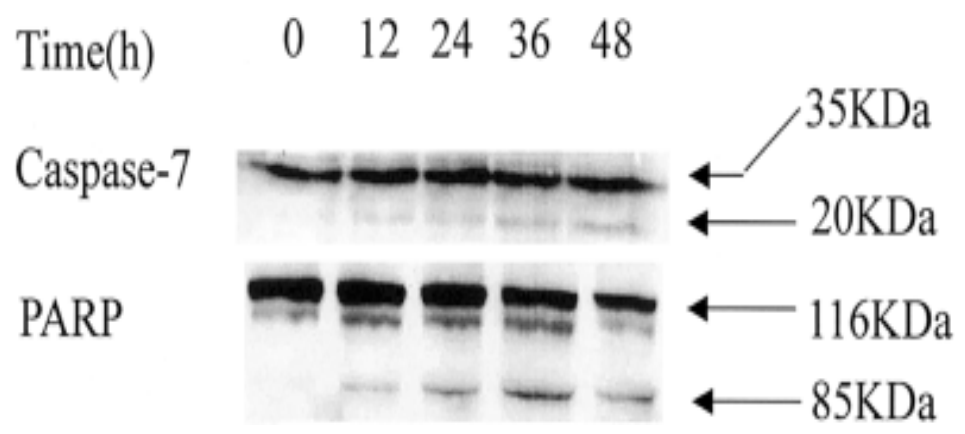

Figure.3 Effect of alcohol extract of Ganoderma lucidum on expression of caspase-7 and PARP in MCF-12 cells

Effects of alcohol extract of Ganoderma lucidum on the levels of P53, bax and Bcl-2 in MCF-12 cells

To explore the potential signaling pathways underlying Ganoderma lucidum alcohol extract-induced apoptosis, we evaluated transcription factor p53 and Bcl-2 family proteins by Western blot. The Bax protein level was increased $12 \mathrm{hr}$ after treatment and remained elevated up to $48 \mathrm{hr}$. No change was observed in protein expression of Bcl-2 (Fig. 2). The results suggested that Ganoderma lucidum induced apoptosis in MCF-12 cells might be medi- ated through up-regulation of Bax pathway.
Effects of alcohol extract of Ganoderma lucidum on the caspase-7 and PARP expression and cleavage in MCF-12 cells

To assess the role of caspase-7 in this apoptotic process, the expression of caspase-7 was examined by Western blot analysis. As shown in Figure 3 , the $35 \mathrm{kD}$ proenzyme caspase-7 was cleaved to its active $20 \mathrm{kD}$ form $12 \mathrm{hr}$ after treatment in a time-dependent manner. The $116 \mathrm{kD}$ PARP protein was cleaved to $85 \mathrm{kD}$ fragment in a timedependent manner to a maximum level at 36 hr.

This research work has shown that alcohol extract of Ganoderma lucidum inhibited cell 
proliferation and induced apoptosis in human breast cancer cells. Furthermore, we demonstrated that alcohol extract of Ganoderma lucidum induced cell growth arrest through up-regulation of p21, downregulation of $\mathrm{E} 2 \mathrm{~F}$ and cdk4 induced apoptosis through increasing the function of Bax protein expression and activation of caspase-7. Importantly, the alcohol extract of Ganoderma lucidum has no such effects on nontumorigenic WB cells, indicating that it might be selectively cytotoxic for the tumor cells (data not shown). This can be examined in normal human breast epithelial cells and other breast cancer cell lines in further studies.

In case of mammalian cells, replication is regulated in an orderly fash- ion from G1 to $S$ to mitosis by phase-specific oscillations in the level of cyclins, cyclin-dependent protein kinases (cdks) and cdk inhibitors. Cell cycle progression is accelerated by cyclins and cdks, and decelerated by cdk inhibitors (such as p16, p21 and p27), p53, retinoblastoma tumor suppressor protein (RB) and by ARF. The D-type cyclins (cyclin D1, D2 and D3) are involved in regulation of transition from G1 to S during cell cycle. Their critical function is to activate cdk4 and cdk6.22 Recent studies have shown that alcohol extract of Ganoderma lucidum can induce significant reduction in $\mathrm{LNCaP}$ cell growth. 18 It has been reported that the alcohol extract of Ganoderma lucidum can inhibit cell growth by preventing the transition from G1 to $\mathrm{S}$ phase in HeLa cells.17 Consistent with these previous reports, in this study we also observed that the alcohol extract of Ganoderma lucidum was capable of inducing cell cycle arrest at G1 phase in MCF-12 cells. Further mechanistic study suggested that this process might be mediated through upregulation of p21 and down-regulation cyclin $\mathrm{D} 1$, which inhibited or inactivated cdk4 and led to the dephos- phorylation of RB. This in turn resulted in the inactivation of the transcription factors E2F, involved in the expression of genes required for DNA synthesis and cell cycle progression. Many investigators have suggested that the antitumor effect of Ganoderma lucidum might be mediated by host responses.10 -12 Wang et al.10 reported that the anti-tumor activities of water extract-po- lysaccharides of Ganoderma lucidum (PS-G) was mediated by cytokines released from activated macrophages and $\mathrm{T}$ lymphocytes, especially TNF-a and IFN- $\mu$. These cytokines in turn induced apoptosis and differentiation in the treated leukemic cells. PS-G alone, however, can not directly induce apoptosis in the treated leukemic cells. Our results for the first time demonstrate that the alcohol extract of Ganoderma lucidum is directly capable of inducing apoptosis in human breast cancer cells, not through immune system. Our results further show that this apoptotic pro- cess might be mediated through up-regulation of BAX, a member of Bcl-2 family. The proapoptotic Bax protein led to mitochondrial dysfunction and the release of cytochrome $\mathrm{c}$ (Cyt c) from the mitochondria. The released Cyt $\mathrm{c}$ then interacts with specific adapter, such as Apaf-1, which in turn proteolytically converts procaspases to active caspases. One key step of this cascade in MCF-12 cells was activation of caspase-7, which cleaves several substrates including the PARP, a nuclear enzyme involved in DNA repair and maintenance of genome integrity and posttranslational ribosylation of proteins, whereby apoptosis occurs. We found that the inactive caspase-7 precursor was cleaved to the $20 \mathrm{kD}$ subunit forming the active protease during apoptosis. This occurred in conjunction with cleavage of $116 \mathrm{kD}$ PARP to $85 \mathrm{kD}$ proteolytic fragments. Our results suggest that caspase- 7 may be the main effector caspase in caspase-3-deficient MCF-12 cells during apoptosis. The results are consistent with other reports using MCF-12 cell system.23-25 
In short, alcohol extract of Ganoderma lucidum inhibits cell proliferation through down-regulation cyclin D1 and up-regulation of p21, and induces apoptosis through over expression of Bax protein in human breast cancer cells. Our research work thus suggests multiple mechanisms underlying the antitumor effects of Ganoderma lucidum.

\section{References}

1. Lee KW, Lee HJ, Kang KS, Lee CY. Preventive effects of Vitamin $\mathrm{C}$ on carcinogenesis. Lancet 2002; 359:172.

2. Kang KS, Yun JW, Lee YS. Protective effect of L-carnosine against 12-0tetradecanoylphorbol-13-acetate- or hydrogen peroxide-induced apoptosis on vmyc transformed rat liver epithelial cells. Cancer Lett 2002; 178:53-62.

3. Kang KS, Yun JW, Yoon BS, Lim YK, Lee YS. Preventive effect of germanium dioxide on the inhibition of gap junctional intercellular communication by TPA. Cancer Lett 2001; 166:147-53.

4. Kang KS, Kang BC, Lee BJ, Che JH, Li GX, Trosko JE, Lee YS. Preventive effect of Epicatechin and Ginsenoside Rb2 on the inhibi- tion of gap junctional intercellular communication by TPA and $\mathrm{H} 2 \mathrm{O} 2$ Cancer Lett 2000; 152:97-106.

5. Kitts DD, Lim KT. Antitumorigenic and cytotoxic properties of an ethanol extract derived from Rhus verniciflua stokes (RVS). J Toxicol Environ Health A 2001; 64:357-71.

6. Grube BJ, Eng ET, Kao YC, Kwon A, Chen S. White button mush- room phytochemicals inhibit aromatase activity and breast cancer cell proliferation. J Nutr 2001; 131:3288 -93.

7. Suganuma M, Ohkura Y, Okabe S, Fujiki $\mathrm{H}$. Combination cancer chemoprevention with green tea extract and sulindac shown in intestinal tumor formation in Min mice. $\mathrm{J}$ Cancer Res Clin Oncol 2001; 127:69 -72.

8. Cho JH, Cho SD, Hu HB, Kim SH, Lee YS, Kang KS. The roles of ERK1/2 and p38
MAP Kinases in the preventive mechanisms of mushroom Phellinus linteus against the inhibition of gap junctional intercellular communication by hydrogen peroxide. Carcinogenesis 2002; 23:1163-9.

9. Trosko JE, Chang CC. Mechanism of upregulation gap junctional intercellular communication during chemoprevention and chemother- apy of cancer. Mutat Res 2001; $480-481: 219-29$.

10. Wang SY, Hsu ML, Hsu HC, Tzeng CH, Lee SS, Shiao MS, Ho CK. The anti-tumor effect of Ganoderma lucidum is mediated by cytokines released from activated macrophages and $\mathrm{T}$ lymphocytes. Int $\mathrm{J}$ Cancer 1997; 70: 699-705.

11. Zhang Q, Lin Z. Study on antitumor activity and mechanism of Ganoderma polysaccharides $\mathrm{B}$. Zhongguo Zhong Xi Yi Jie He Za Zhi 1999; 19: 544 -7.

12. Won SJ, Lee SS. Ke YH, Lin MT. Enhancement of splenic NK cytotoxic activity by extracts of Ganoderma lucidum mycelium in mice. J Biomed Lab Sci 1989; 2: 201-3.

13. Kim HS, Kacews S, Lee BM. in vitro chemopreventive effects of plant polysaccharides (Aloe barbadensis miller, Lentinus edodes, Ganoderma lucidum and Coriolus versicolor). Carcinogenesis 1999;20: 1637- 40.

14. Lee JM, Kwon H, Jeong H, Lee W, Lee SY, Baek SJ, Surh YJ. Inhibition of lipid peroxidation and oxidative DNA damage by Ganoderma lucidum. Phytother Res 2001; 15: 245-9.

15. Lu H, Uesaka T, Katoh O, Kyo E, Watanabe H. Prevention of the development of preneoplastic lesions, aberrant crypt foci, by a water- soluble extract from Ganoderma lucidum mycelia in male F344 rats. Oncol Rep 2001;8:1341-5.

16. Lu H, Kyo E, Uesaka T, Katoh O, Watanabe H. Prevention of development of $\mathrm{N}, \mathrm{N}$-dimethylhydrazine-induced colon tumors by a water-soluble extract from cultured medium of Ganoderma lucidum mycelia in male ICR mice. Int $\mathbf{J}$ Mol Med 2002;9:113-7. 
17. Zhu HS, Yang XL, Wang LB, Zhao DX, Chen L. Effects of extracts from sporodermbroken spores of Ganoderma lucidum on HeLa cells. Cell Biol Toxicol 2000; 16: 201-6.

18. Hsieh TC, Wu JM. Mechanism of action herbal supplement PC-SPES: elucidation of effects individual herbs of PC-SPES on proliferation and prostate specific gene expression in androgen-dependent $\mathrm{LNCaP}$ cells. Int J Oncol 2002; 20: 583-8.

19. Bao XF, Wang XS, Dong Q, Fang JN, Li $X Y$. Structural features of immunologically active polysaccharides from Ganoderma lucidum. Phytochemistry 2002; 59: 175-81.

20. Hack-Frenascho M, Kino K, Sone T, Jardieu P. Ling zhi-8: a novel $\mathrm{T}$ cell mitogen induces cytokine production and upregulation of ICAM-1 expression. Cell Immunol 1993; 150: 101-13.

21. Cheung WM, Hui WS, Chu PW, Chiu SW, Ip NY. Ganoderma extract activates MAP kinases and induces the neuronal differentiation of rat pheochromocytoma PC12 cells. FEBS Lett 2000; 486: 291-6.

\section{How to cite this article:}

Reetu Gour and Garg, A.P. 2020. In-vitro Analysis of Ganoderma lucidum Extract Induces Cell Cycle Arrest and Apoptosis in MCF-12 Human Breast Cancer Cell. Int.J.Curr.Microbiol.App.Sci. 9(09): 3252-3259.

doi: https://doi.org/10.20546/ijcmas.2020.909.403 